\title{
Assessing Tropical Deforestation and Biodiversity Loss in the Cross River Rainforest of Nigeria
}

\author{
Oliver 0. O. Enuoh' ${ }^{1}$, Augustine U. Ogogo ${ }^{2}$ \\ ${ }^{1}$ Department of Forestry and Wildlife Resources Management, University of Calabar, Calabar, Nigeria \\ ${ }^{2}$ Faculty of Agriculture, University of Calabar, Calabar, Nigeria \\ Email: oliverenuoh@yahoo.com, oenuoh@unical.edu.ng, auogogo@unical.edu.ng
}

How to cite this paper: Enuoh, O. O. O., \& Ogogo, A. U. (2018). Assessing Tropical Deforestation and Biodiversity Loss in the Cross River Rainforest of Nigeria. Open Journal of Forestry, 8, 393-408. https://doi.org/10.4236/ojf.2018.83025

Received: June 15, 2018

Accepted: July 24, 2018

Published: July 27, 2018

Copyright $\odot 2018$ by authors and Scientific Research Publishing Inc. This work is licensed under the Creative Commons Attribution International License (CC BY 4.0).

http://creativecommons.org/licenses/by/4.0/

\begin{abstract}
The Cross River Rainforest of South Eastern Nigeria is one of Africa's last remaining areas of pristine tropical high forest, extremely rich in a wide variety of flora and fauna species, and is among the twenty five biodiversity hotspots in the world. The forest has important biophysical properties which affect local, regional and global environmental quality. Using a combination of document research, GIS report, field observations, interviews and focus group discussions, the study reveals that the ecological integrity of this forest is being seriously threatened by a myriad of human activities, such as unsustainable agricultural practices, illegal logging, population explosion/expansion of human settlements, construction of highways, mining activities, and high unemployment/pressure on natural resources. All the above factors have combined to impact heavily on the depletion and extinction of valuable flora and fauna species in the region. Rigorous research-based innovative forestry and biodiversity policies and programmes, forest restoration initiatives, community-based forest management, and sustainable land use practices are recommended to save the Cross River Rainforest from total destruction.
\end{abstract}

\section{Keywords}

Tropical Rainforests, Illegal Logging, Deforestation, Agriculture, Biodiversity Loss

\section{Introduction}

Tropical rainforests are "the most species-rich natural environments on Earth, and have extremely important biophysical properties which affect local, regional 
and global environmental quality" (WWF/ODNRI, 1989: p. 1). Terborgh \& Schaik (2002: p. 4) maintain that $75 \%$ or more of the Earth's biological diversity resides in the tropics. Oates (2002: p. 65), comment that the Cross River Rainforest of South Eastern Nigeria is a global biodiversity hotspot and region of species endemism. Unfortunately, tropical rainforests especially in West Africa are under increasing pressure from growing human populations, and from the consequent demands for new land for agriculture, urbanization, and industrial development (Burley, 1997). Ojong (1996: p. 148) observes that "over 90\% of the rainforest of South Eastern Nigeria has been devastated through massive illegal logging activities, careless deforestation, urbanization, subsistence farming and plantation agriculture. What is left is less than $10 \%$ from which the Cross River National Park (CRNP) was established under decree 36 of 1991 to conserve its biodiversity."

Prior to the advent of colonialism in Nigeria in the 1800s, different ethnic or tribal kingdoms existed and had land boundaries that protected their intact natural resources from external exploitation and misuse. Nigeria's rainforest was thus blessed with various flora and fauna species. For flora, examples include trees such as Baillonella toxisperma, Pterocarpus osun, Brachystegia spp., Etandrophragma spp., Terminalia ivorensis, Milicia excels, Poga Oleosa, Piptandeniastrum africanum, etc. For fauna, examples include Panthera pardus (Leopard), Gorilla, Elephants, Chimpanzees, Buffaloes, Potamochoerus porcus (Bush Pig), Papio Anubis (Baboon), assorted monkey species, etc. The British colonization of Nigeria, and subsequent nationalization and commercialization of forest resources culminated in community alienation in forest management and the emergence of a culture of utilitarianism and recklessness in the use and management of these resources. Government and private forest resources exploitation initiatives (e.g. commercial timber logging in government forest reserves), exacerbated overexploitation of these resources. The above is the colonial root of deforestation activities in Nigeria, which have remained unchanged even after Nigeria's national independence on October $1^{\text {st }}, 1960$.

During British colonial rule, a forest policy was imposed which nationalized over $80 \%$ of communal forest lands by way of Government Forest Reserves, leaving the balance as community forest. Marguba (2003: p. 19) informs that during colonial rule, the British established 1129 Forest Reserves, 30 Game Reserves, and 5 Game Sanctuaries in Nigeria. Villagers were persuaded to support the policy, with assurance that forest reservation laws were meant to secure the forest for future generations. A serious surprise then came in the 1940s when the colonial authorities introduced and started approving timber logging concessions to various British companies like Glikstens, Cobbert \& Co, UAC (United Africa Trading Company), Brandler and Rylke Timber Company, African Timber and Plywood Company (AT \& P), South Eastern Romanian Wood (SEROWOOD) Ltd, Calabar Veneer and Plywood Company Ltd, etc.

These companies embarked on reckless and unsustainable logging operations that created and sustained the deforestation trends that have persisted in Nigeria 
till the present day. Government revenue basically came from these exploitations, and so Government condoned deforestation and the reckless forestry practices of the logging companies. In a book "Out of Nigeria: Witness to a Giant's Toil", Joseph L. Brandler, author and Managing Director of the above Brandler and Rylke Ltd, London, commented that:

“The tropical logger is not popular in today's society. The uncontrolled felling of trees, particularly in the Amazon Basin, has given him a bad name. The colonial administration and its successor states were (and are) aware of the importance of forest management and conservation of trees. At the same time, they knew that logging had to be supported and were careful to cooperate with the timber companies...The use of timber for firewood, house construction, tools, weapons, furniture and so on must be as old as civilization itself. The abundance of trees in the forest belt of West Africa, stretching from Sierra Leone right down to Angola and South thereof, lend themselves to these activities" (Brandler, 1993: p. 76).

Governments in developing countries, especially Nigeria are thus agents of deforestation, hinging on the colonial legacy of forest nationalization and commercialization. Out of Nigeria's 36 States, 17 are in the southern or coastal region, while 19 are in the north. The southern states belong to the tropical high forest region, while the northern states belong to semi-arid and arid regions of the country. 58 years of nationhood (1960-2018) has witnessed serious deforestation in Nigeria's southern (rainforest states), to the extent that over $90 \%$ of the country's forest resources are lost (WWF/ODNRI, 1989). The rainforest of Cross River State (South Eastern Nigeria), is now the major area where pristine forest still remains in the country. Though a significant part of this forest is now a national park (Cross River National Park), other large areas that remain as government forest reserves and community forests are still seriously threatened by various human activities, culminating in continuous depletion and extinction of flora and fauna species in the region.

FAO (2010: p. 20) maintain that for the past two decades, Nigeria has been experiencing deforestation rates which averages $2.7 \%$ per annum. FAO estimates that between 1976 and 1990, Nigeria's deforestation proceeded at an average rate of 400,000 hectares per annum or $3.5 \%$ (www.un.org/esa/agenda21/natlinfo/countr/nigeria/natur.htm). FAO concludes that if the above rate of deforestation is maintained, the remaining forest area in the country will disappear by the year 2050. The above trend has affected the biodiversity rich Cross River Rainforest. Cross River State Forestry Project (DFID assisted, 2002: p. 15), undertook an assessment of the State's forest and subsequently calculated areas of land cover types, and reported that out of over 2 million hectares of rainforest originally found in the State, primary forest remaining was only 729,000 hectares. This shows a very high rate of deforestation. There is growing international concern on the shrinking nature of Cross River 
rainforest and the disappearance of various flora and fauna species in the State.

Dunn \& Otu (1996: p. 35) attribute the alarming rate of deforestation in South Easter Nigeria to the failure of government policy, quest for government revenue and the pegging of budgetary revenue targets that are tied to forest exploitation. The influence of forestry practices from some neighboring countries in West Africa also has negative impacts on forestry practices in South Eastern Nigeria. For instance, in neighboring Ivory Coast, the Government has been pursuing since independence, destructive forestry practices so as to earn foreign exchange and tax revenues (World Bank, 1985: p. 2). The World Bank maintains that "...loggers continue to exploit the remaining forests, more or less uncontrolled, and farmers have followed roads developed for logging operations establishing cocoa, coffee, and food crops, with the wide spread practice of slash and burn farming. Such intrusions have also begun in the classified forest reserves and national parks. Government now estimates that this process transforms about 0.4 million hectares of unspoiled high forest per year" (World Bank, 1985: p. 2).

IUCN (1996: p. 1) maintain that colonial nationalization of much of the world's forest and poor forest management practices by Forestry Departments in developing countries is responsible for the alarming rate of tropical deforestation. Bromley (1992: p. 77) similarly observes that "Governments who have appropriated forests from local level management bodies-primarily villages-and have failed to manage them in an effective manner have created de jure state property, but de facto open access. The absence of effective management and enforcement has simply turned the forest into a resource that can be exploited on a first come, first served basis."

On the way forward to deal with tropical deforestation especially in Africa, Besong (1997: p. 7) maintains that "Government Departments alone can no longer undertake all the monitoring and coordination of forestry activities because of limitations in personnel and financing. New arrangements should involve all the actors (major users) who should contribute personnel and/or finances. Local communities can, for example, contribute man power for monitoring purposes although they will require training." Arguing in the same vein, Lengeler (1997: p. 43) opines that "local communities should be involved in forest management in the tropics and given some training skills to enable them perform such roles well. "Bisong (1994) recommends agricultural intensification in forest communities as panacea for slash and burn agriculture which is the greatest cause of tropical deforestation".

This paper assesses the threats and current level of deforestation in the rainforest region of Cross River State and its biodiversity conservation impacts, and stresses the need for local, national and global action to save this forest, in view of its status as a global biodiversity hotspot and region of species endemism.

\section{Research Methods}

\subsection{Geographical Location}

Nigeria is located on the West Coast of Africa, between latitudes $4^{\circ} 15^{\prime} \mathrm{N}$ (the 
southern tip of the Niger Delta and the Atlantic Ocean) and $13^{\circ} 55^{\prime} \mathrm{N}$ (the north western frontier with Niger Republic), and between longitudes $2^{\circ} 45^{\prime} \mathrm{E}$ (the southern frontier with Benin Republic) and $14^{\circ} 40^{\prime} \mathrm{E}$ (the northern frontier with Cameroon Republic). The country occupies a total land area of 923,768 sq km and a total human population of 180 million people. In terms of geo-political units, Nigeria comprises 36 states and 774 Local Government Areas or Local Counties. Her vegetation comprises belts of mangrove swamps in the coastal region, followed by fresh water swamps, then tropical rainforest, then Guinea Savanna (woodland with stunted trees and tall grass), then Sudan Savanna (land with short grass), then Sahel or marginal savanna (land with or without short grass), and montane or highland vegetation. Climatic variations include equatorial to the south, tropical in the centre, and arid in the north. Mean maximum temperatures are $30^{\circ} \mathrm{C}-32^{\circ} \mathrm{C}$ in the south, and $33^{\circ} \mathrm{C}-35^{\circ} \mathrm{C}$ in the north. Annual rainfall decreases northward, about 2000 millimeters in the coastal region (Niger Delta averages over 3550 millimeters), and 500 - 700 millimeters in the north (WWF/ODNRI, 1990: p. 16).

The study area (Cross River State and the Cross River rainforest) is contiguous in landmass with the forest of southern Cameroon, and Cameroon's Korup National Park, lying between latitude $4^{\circ} 28^{\prime}$ and $6^{\circ} 55^{\prime}$ North of the Equator, and longitude $7^{\circ} 50^{\prime}$ and $9^{\circ} 28^{\prime}$ East of the Greenwich meridian. FAO (2010: p. 36) estimates that around 2.9\% of Nigeria's forest cover consist of primary forest which is relatively intact, and the bulk of it is in South Eastern Nigeria (Cross River State). The State shares common boundaries with the Republic of Cameroon in the East, Benue State of Nigeria in the North, Ebonyi and Abia States of Nigeria in the West, Akwa Ibom State of Nigeria in the South West, and the Atlantic Ocean in the South.

\subsection{Data Collection and Analysis}

The study was cross sectional, cutting across government forest reserves and community forests in Cross River State. The methods used for data collection comprise document research at Cross River State Forestry Commission (CRSFC) and Cross River National Park (CRNP), and participatory rural appraisal exercises (e.g. historical timeline assessment of deforestation, focus group discussions, interviews and field observations), and GIS (Global Information System) reports. For the quantitative data, responses from administered questionnaire were entered into SPSS (version 17) for statistical analysis. All variables were coded with measurements defined as nominal, ordinal and scale. Based on the nature of research questions for the study, descriptive statistics were used in the analysis, to look for patterns in the data set.

\section{Results}

Findings reveal that tropical deforestation in the Cross River rainforest (South Eastern Nigeria) has over the years been exacerbated by a combination of human factors. 


\subsection{Government and the Failure of Forest Policies and Programs}

It was discovered that the nationalization of forest territories hitherto belonging to communities as Government Forest Reserves in the 1930s (during British Colonial Rule), and subsequent commercialization (approval of logging concessions) in government forest reserves (from the 1950s), marked the beginning of tropical deforestation in Cross River State. The Cross River State Forestry Project (ODA assisted) of 1991 carried out a proper scientific assessment of the forest still remaining in Cross River State. Remotely sensed photos/maps, GIS mechanisms, land use surveys, and statistical calculations were carried out which provided information about the status of primary forest left in government forest reserves in the state (see Table 1).

The forest vegetation map of Cross River State (see Figure 1) produced by the Cross River State Community Forestry Project-DFID assisted), in 2002 shows the level of deforestation in the state.

The above map is now 16 years old, thus further deforestation must have occurred.

GIS report on Land Cover Change in Okwangwo Division of CRNP/Mbe Mountain region also offer useful insight on the levels of deforestation in the Cross River rainforest. The analysis by WCS/Okeke (2013), carried out on

Table 1. Deforestation in government forest reserves in cross river state.

\begin{tabular}{|c|c|c|c|c|}
\hline S/No & Name of Forest Reserve & Year Constituted & Area $\left(\mathrm{Km}^{2}\right)$ & $\%$ of deforestation \\
\hline 1 & Afi River Forest Reserve & 1930 & 383.32 & $31 \%$ Cleared \\
\hline 2 & Agoi Forest Reserve & 1940 & 46.62 & $33 \%$ Cleared \\
\hline 3 & Boshi Forest Reserve & 1951 & 41.44 & $51 \%$ Cleared \\
\hline 4 & Boshi Extension F.R. & 1958 & 67.34 & $35 \%$ Cleared \\
\hline 5 & Cross River North F.R. & 1930 & 129.50 & $61 \%$ Cleared \\
\hline 6 & Cross River South F.R. & 1930 & 349.65 & $21 \%$ Cleared \\
\hline 7 & Ekinta Forest Reserve & 1953 & 108.78 & $89 \%$ Cleared \\
\hline 8 & Gabu & 1960 & 5.18 & $100 \%$ Cleared \\
\hline 9 & Ikom Fuelwood plantation & 1960 & 1.06 & $100 \%$ Cleared \\
\hline 10 & Ikrigon Forest Reserve & 1928 & 5.29 & $100 \%$ Cleared \\
\hline 11 & Lower Enyong F.R. & 1930 & 28.49 & $100 \%$ Cleared \\
\hline 12 & Oban Group F.R. & 1912 & 3742.55 & Now CRNP \\
\hline 13 & Okwangwo F.R. & 1930 & 468.79 & Now CRNP \\
\hline 14 & Ukpon River F.R. & 1930 & 313.39 & $16 \%$ Cleared \\
\hline 15 & Umon Ndealeachi F.R. & 1930 & 108.78 & $49 \%$ Cleared \\
\hline 16 & Uwet Odot F.R. & 1930 & 284.90 & $38 \%$ Cleared \\
\hline \multirow[t]{2}{*}{17} & Yache Forest Reserve & 1931 & 15.54 & 100\% Gmelina \\
\hline & Total & & 6101.29 & \\
\hline
\end{tabular}

Source: Cross River State Forestry Project (1994) (ODA-Assisted) - Forest Inventory Report. 


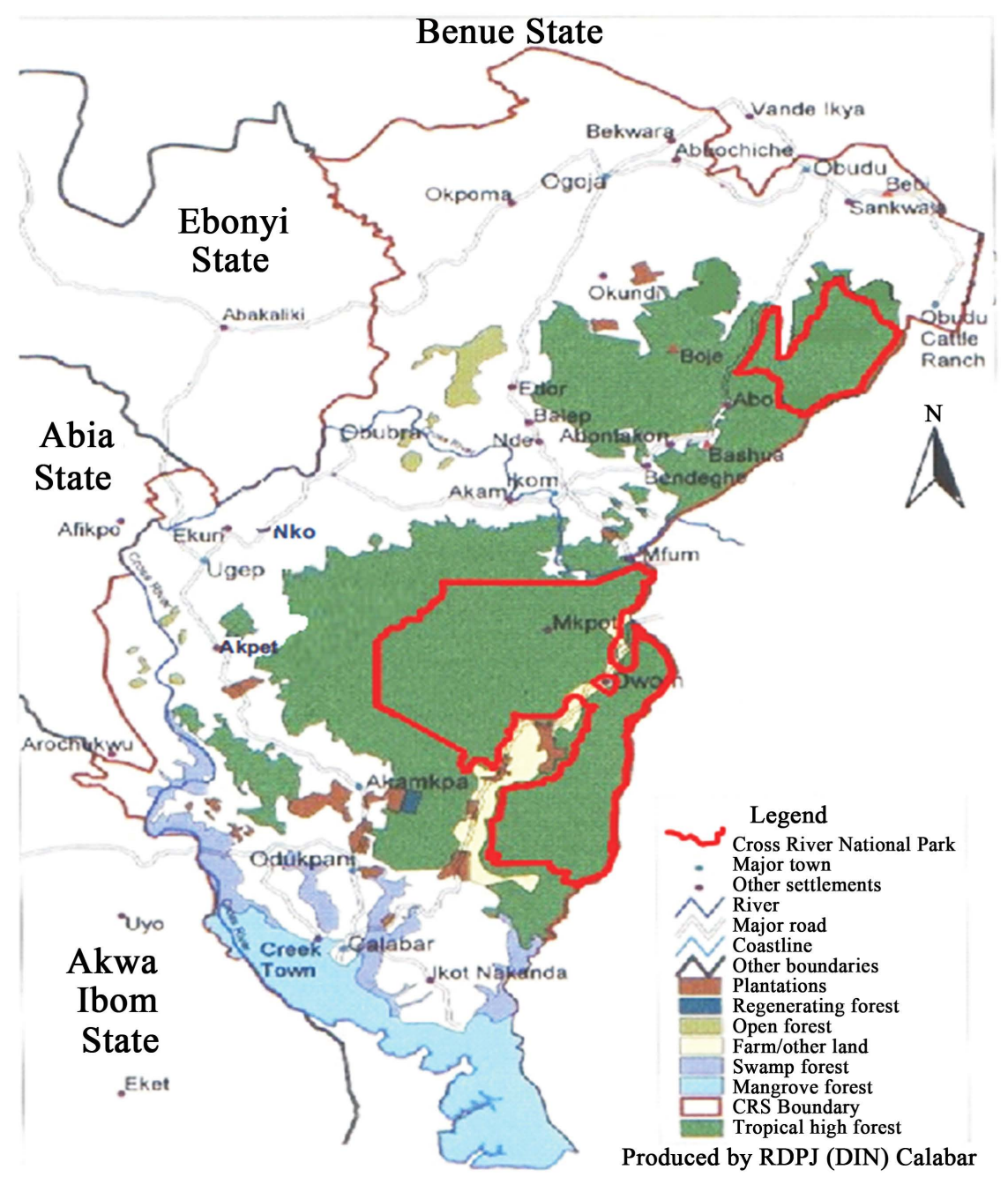

Figure 1. Map of cross river state showing the level of deforestation in the state.

multi-temporal change for two periods (1986-2000 and 2000-2010), demonstrate that there is significant increase in deforestation rate in the 2000-2010 period (2.22\%) when compared with the rate seen in the $1986-2000$ period (0.09\%). Overall, the result shows a staggering loss of $21.15 \%$ of the forest in the Afi-Mbe-Okwangwo landscape from 1986 to 2010. Deforestation appears to be highest in the Afi River Forest Reserve (ARFR) where annual deforestation increased twelve-fold from only 227 ha between 1986 and 2000 to 2760 ha from 2000 to 2010, followed by Afi Mountain Wildlife Sanctuary (AMWS) where annual deforestation doubled for the same period. The Mbe Mountains had the lowest rate of deforestation $(0.04 \%$ and $0.19 \%$ for the two time periods respectively), followed by Okwangwo (0.04\% and $0.27 \%)$. As the Mbe Mountains was only designated a community forest in 2005 , its protection effort by the community with support from WCS may explain this low rate. However, given the double-fold increase in the deforestation rate from one time period to the next, it seems that the Afi Mountain Wildlife Sanctuary is becoming vulnerable to increased pressure in the area (Figure 2). 

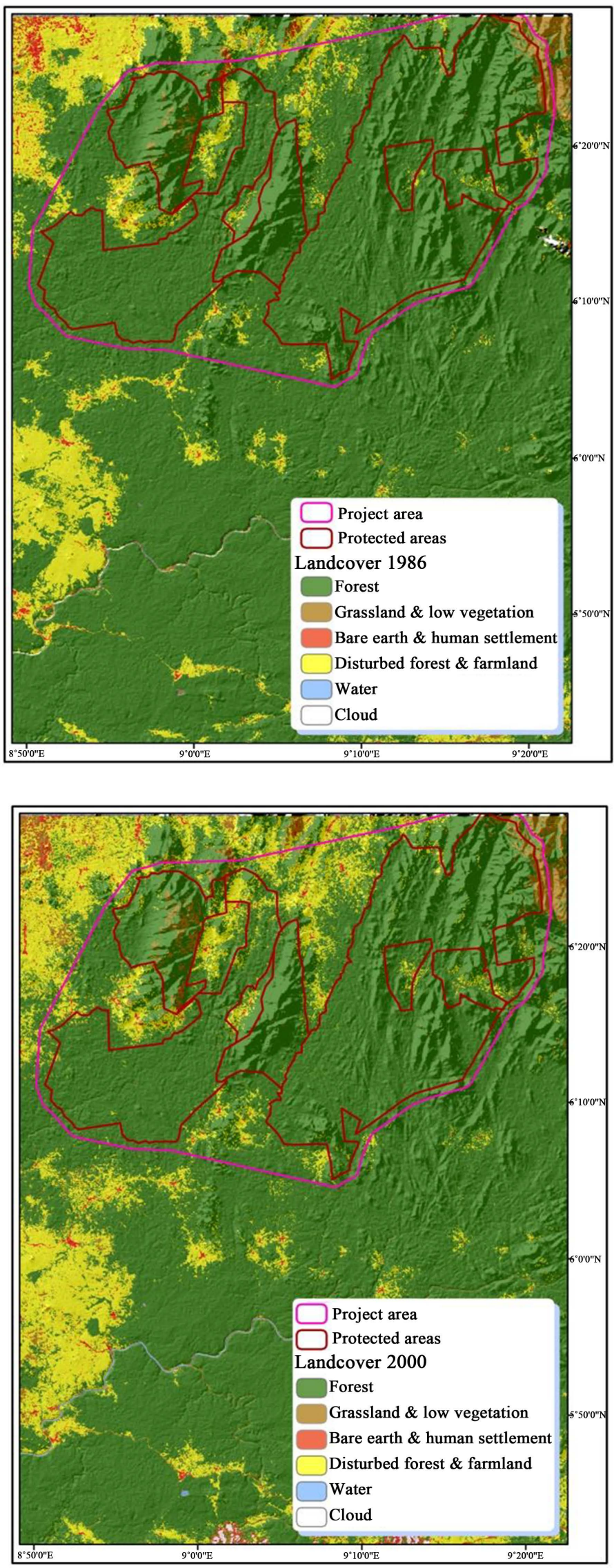


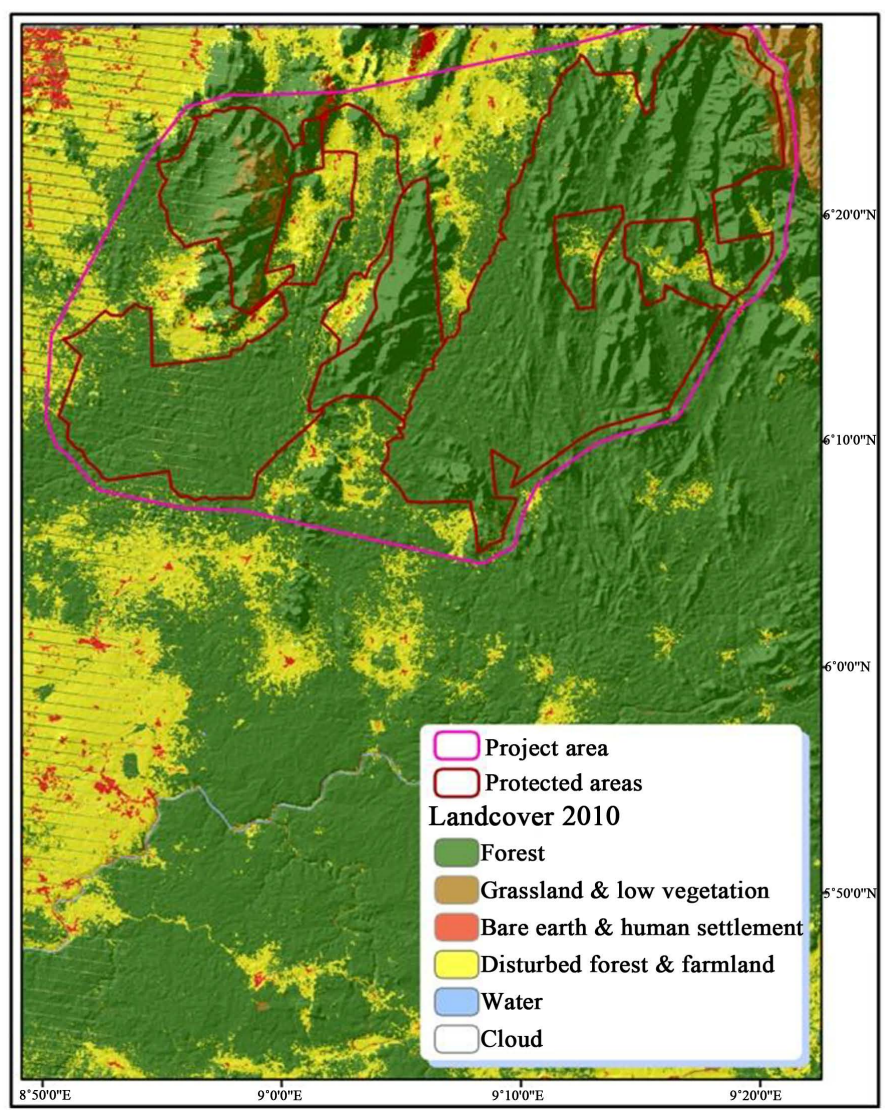

Figure 2. Comparison of Land cover change in Okwangwo Division of CRNP and Mbe Mountain region for 1986 (Landsat TM data), 2000 (Landsat ETM + data) and 2010 (Landsat ETM + data). Source: WCS/Okeke, 2013.

\subsection{Establishment of Government Agricultural Plantations}

From the colonial days up to the present period, several tree crops such as rubber, cocoa, palm trees, cashew, cotton, etc., and non-tree crop plantations such as banana, plantain, cassava, pineapple, etc., were established by government all over Nigeria. In Cross River State, examples include oil palm estates at Calaro, Ibiae, Oban, Borum and Nsadop; rubber plantations at Uyanga-Akamkpa, Nko, Biakpan, Ikot Okpora, and Agoi; cocoa plantations at at Ikom and Etung group of estates; and Gmelina arborea plantations at Awi and Edondon group of communities/estates. These plantations were established to broaden or diversify the revenue base of government which resulted in massive primary forest clearance across several Local Government Areas (Local Counties) in South Eastern Nigeria.

\subsection{Slash and Burn Agricultural Practices in Rural Communities}

The State wide practice of slash and burn agriculture in all local communities in the region, with no legal restrictions over the years, has culminated in perpetual destruction of the rainforest by local people. There are no land use plans guiding land use practices. There are over 2500 local communities with a population of 
2.1 million people in Cross River State. This high population has resulted in the continuous establishment and government recognition of new village settlements. Migrant populations from other parts of the country where forest has been exhausted are also adding to the pressure on the remaining forest resources in the area.

\subsection{Construction of Highways and Feeder Roads}

Government development plans and determination to link all forest/local communities with good roads has impacted negatively on forest resources exploitation. For instance, the opening of the Calabar-Ikom-Ogoja-Obudu road (from north to south of the state), and a network of adjoining feeder roads have exposed hitherto inaccessible and intact forest to reckless illegal logging activities and hunting of wild animals. The ubiquity of logging roads, opened by logging companies is further attracting farmers and migrant populations to open new farm lands and hunting grounds in biodiversity rich pristine forest areas. In 2016, the government of Cross River State came up with a new proposal to construct a superhighway across the core area of the remaining pristine rainforest in the state. The Federal Ministry of Environment has on three occasions rejected all EIA (Environmental Impacts Assessment) reports on the superhighway, and NGOs, forest communities, and the international community have all protested against the project in different ways. So far the government of Cross River State is still determined to carry on with the project. The proposed superhighway poses the greatest threat to the rainforest of Cross River State in recent time.

\subsection{Mining and Quarrying Activities}

Granite quarrying activities in places like Old Nnetim, Obung, Nsan, Akamkpa urban, Awi, Mbarakom, Uyanga, Ojor, etc.; and mining of limestone for the cement factory at Mfamosing, Aningeje, Mbobui, Abiati, and other Ojuk clan villages, have contributed immensely towards serious deforestation and depletion of valuable flora and fauna species in the affected communities. The absence of official regulations controlling ecological abuses by the quarrying and mining companies involved, have also aided rapid deforestation in the region. The Cross River State Government is hardly committed to the strict enforcement of environmental impacts assessment laws of Nigeria across the state. Hardly are quarrying and mining companies engaging in forest ecological restoration activities to address their negative environmental impacts.

\subsection{Hunting by Bush Burning}

The practice of some local people and communities setting large portions of primary forest ablaze for hunting purposes (to kill wild animals), has also impacted negatively on the integrity of Cross River State's rainforest. The tragedy of the foregoing deforestation and loss of biodiversity problems in Cross River State, lies not in the excesses of the perpetrators, but in the failure of government to enforce the appropriate forestry and wildlife management laws of the state. 


\subsection{Common Property Regimes and Open Access}

The communal ownership of forest lands designated as Community Forests have also not helped matters. Such forests belong to all citizens of the affected communities, and so everybody have rights to go into the forest and undertake the extraction of timber and non timber forest products as they like. One can clear primary forest for new farm lands as much as what one desires. This free for all approach to forest resources management has culminated seriously in the present level of deforestation in the region.

\subsection{The Impacts of Deforestation on the Flora and Fauna Resources of Cross River State}

On the strength of the foregoing deforestation activities in Cross River State, there are serious consequences on the flora and fauna resources of the region. On the floral side of the coin, certain government forest reserves have either become seriously depleted, or wiped out almost completely. Dunn \& Otu (1996: p. 35) report the case of Ekinta Government Forest Reserve in Akamkpa Local Government Area of the State:

"Ekinta, an 11,000 hectares forest reserve in the South East of the State, provides a good example of accelerated high forest loss as a consequence of forest policy that favored forest exploitation and the establishment of fast growing exotic species. The reserve was good quality high forest until the late 1970s. The government owned logging company-SEROMWOOD, cleared much of the forest in a salvage cut and opened up the entire reserve with a network of roads. A large number of farmers (from the then south-west of CRS, now the neighboring State of Akwa Ibom) were permitted to move into the area to establish plantations of Gmelina arborea using the taungya system. However, due to a shortage of funds for seedlings and supervision, virtually no plantations were established. In less than a decade, $90 \%$ of the forest reserve had become cassava farms instead of forest plantations, with hardly a tree standing."

Valuable timber species such as Iroko (Milicia excels), Mahogany (Khaya spp), Black Afara (Terminalia ivorensis), Mimusups (Baillonella toxisperma), White Afara (Terminalia superba), Cedar (Lovoa trichilloides), Ebony, etc. that used to be very common in Cross River State, are now extremely scarce and difficult to find. If available, the prices are so astronomical that only those at the upper echelon of society can afford to buy them. In some local communities, people are beginning to roof their houses with Gmelina arborea, a thing that now surprise the local people themselves. Some people who are crazy of the above high profile timber species are beginning to import wood from the neighboring Republic of Cameroon for domestic furniture use.

On the fauna side, several wild animal species have become extinct, some critically endangered, and some that were hitherto common have also become endangered. Extinct species include among others Leopards, Bush cow, African 
giant pangolin, etc. Critically endangered include Chimpanzee (Pan troglodytes), Drill (Mandrillus leucophaeus), Gorilla (Gorilla gorilla diehli), Preuss's monkey (Cercopithecus preussi), Red bellied monkey (Cercopithecus erythrogaster), Sclater's guenon (Cercopithecus sclateri-endemic to Nigeria), Wild dog (Lycaon pictus). The endangered list include African elephant (Loxodonta Africana), Cheeta (Acinonyx jubatus), Red eared guenon (Cercopithecus erythrotis), Pygmy hippopotamus (Hexaprotodon liberiensis), African pygmy squirrel (Myosciurus pumilio), West African mantee (Trichechus senegalensis), Spotted-necked otter (Lutra maculicollis), etc. (Enuoh, 2012: p. 221).

\section{Discussion}

This paper assesses the major factors underpinning tropical deforestation and biodiversity loss in the Cross River rainforest of Nigeria-a global biodiversity hotspot and region of species endemism. The results indicate that government, the private sector and rural communities are responsible for the alarming rate of tropical deforestation hinging on forest policy and forest management failures (e.g. forest nationalization and subsequent approval of logging concessions in hitherto intact government forest reserves), establishment of government agricultural plantations on government forest reserve lands, construction of highways and rural feeder roads, pursuit of solid minerals mining activities, non-commitment to afforestation or reforestation activities, and the ubiquitous practice of slash and burn agriculture in all rural communities in Nigeria.

Forest landscape fragmentation and decrease of land under forest cover (due to a myriad of unsustainable human land use practices), implies serious impacts on flora and fauna species depletion and extinctions in the region. Both Mcletchie (2002) and Alonso (2004) agree that wherever there is decrease in land under forest cover, the concomitant effect is biodiversity loss or negative change in species evenness and richness. Similarly, Lord \& Norton (1990) are in support that agricultural land clearing activities culminate in biological species extermination and scarcity. Stephanie Flasse, one of the DFID consultants (GIS specialist) involved in the second phase of a DFID-assisted Cross River State Forestry Project (1999-2002), commented in the DFID final project report (prepared in 2003), that Cross River State forests (under current rate of deforestation) will be exhausted by 2033. This has serious implications on the region's biodiversity and the sustainability or survival of endemic primate species like the Cross River Gorilla (Gorilla gorilla diehli), Chimpanzees (Pan troglodytes), Drills (Mandrillus leucophaeus, and other assorted monkey species.

It is important that the remaining tropical rainforest in South Eastern Nigeria (the Cross River Rainforest) be protected in view of its global biodiversity hotspot status and ecological importance. Agbogidi (2011) and Sale et al. (2008) comment that unsustainable human land use activities and the disappearance of many ecologically valued tree species across Nigeria is a well known phenomenon. There is however an urgent need for all stakeholders to reverse this culture 
and trend. It is instructive to note Edet et al. (2015: p. 491) that "if forests are indiscriminately depleted, the various global uses and roles associated with them (economically and ecologically) would be lost." Such loss has huge implications on the quest for global sustainable development and the ecological sustainability of planet Earth itself.

Through the Federal Ministry of Environment, the Government of Cross River State applied and got approval in 2009 for Nigeria's participation in the UNREDD (Reduction of emissions from deforestation and forest degradation) programme, with the Cross River rainforest as pilot site. The tenure of the governor of Cross River State that spearheaded the UNREDD programme came to an end in 2015. The new governor that took over on May $29^{\text {th }} 2015$, was however not impressed with the fact that money from forest carbon (carbon credits), as envisaged in the above programme, had not started accruing to Cross River State since 2009 when the programme was launched. Without openly telling the world that he was pulling Cross River State out of the UNREDD programme, the new governor decided to introduce a super highway project in the state, which was designed in 2016 to pass through the core area of the Cross River rainforest. The project will thus open up the biodiversity rich, intact and Nigeria's last remaining Cross River rainforest for exploitation. NGOs, forest communities, and the international community have all protested in different ways against the proposed superhighway project. The government of Cross River State should do the needful by re-routing the superhighway project to leave the rainforest and biodiversity hotspot areas alone.

\section{Conclusion and Recommendation}

Nigeria has lost over $90 \%$ of her pristine rainforest with an annual deforestation rate of $3.5 \%$ or 400,000 hectares per annum. The Cross River Rainforest, a biodiversity hotspot and Nigeria's last remaining area of pristine rainforest is also experiencing severe threats through various human deforestation mechanisms. These mechanisms comprise colonial forest policy failures, poor public forest management practices, unsustainable/illegal logging activities, establishment of government agricultural plantations, slash and burn agricultural practices in local communities, population explosion/influx of migrants to forest areas, establishment of new rural settlements, construction of highways/feeder rural roads, opening of logging roads, quarrying/mining activities, common property regime/open access to forest resources, and unrestricted hunting of wild animals and other extractive activities. As a consequence, several flora and fauna species have become seriously endangered, and some extinct. Nigeria's deforestation thus has local, national, regional and global ecological implications if current trends are not reversed.

To reverse the above deforestation trend, the following measures should be taken:

1) Change in forest policy-from current centralization/government mono- 
poly of forest management to decentralized/community-based forest and other natural resources management.

2) Ban further logging activities in the remaining rainforest and pursue aggressive reforestation programs in degraded forest reserves.

3) The UNREDD (Reduction of emissions from deforestation and forest degradation) programme in Nigeria, introduced in 2009, with Cross River State/Cross River rainforest as pilot site, should be effectively implemented.

4) Ensure effective management and proper funding of National Parks, especially Cross River National Park in view of its global biodiversity hotspot status and region of species endemism.

5) In-situ conservation initiatives such as captive breeding and re-introduction of extinct or critically endangered fauna species into the wild.

6) Promote agroforestry initiatives and poverty alleviation programs in buffer zone communities of Cross River National Park.

7) Impose hunting restrictions on the hunting of wild animals in the state.

8) Introduce programs to control population explosion (e.g. family planning and birth control) in local communities.

While the above recommendations may not provide all the answers, it is hoped that careful and aggressive implementation will go a long way in charting a new course for effective forest management and biodiversity conservation in Cross River State (South Eastern Nigeria).

\section{Conflicts of Interest}

The authors declare no conflicts of interest regarding the publication of this paper.

\section{References}

Agbogidi, O. M. (2011). A Survey of the Economically Valued Forest Plant Species at the Proposed Site for Airport in Asaba, Delta State, Nigeria. Agriculture and Biology Journal of North America, 2, 143-149.

Alonso, D. (2004). The Stochastic Nature of Ecological Interactions: Communities, Metapopulations, and Epidemies. Ph.D. Thesis, Barcelona: Polytechnic University of Catalonia.

Besong, J. B. (1997). Best Options for Securing the Future of African Rainforests. In African Rainforests and the Conservation of Biodiversity-Proceedings of the Limbe Conference. Limbe: Limbe Botanic Garden.

Bisong, F. E. (1994). Farming Systems, Human Ecology and Resource Conservation in the Cross River Rainforest of Nigeria. Working Paper No. 8 Prepared by the Cross River State Forestry Project (ODA Assisted). Calabar: Forestry Department Headquarters.

Brandler, J. L. (1993). Out of Nigeria: Witness to a Giant's Toils. London: The Radcliffe Press.

Bromley, D. W. (1992). The Commons, Common Property, and Environmental Policy. In Environmental and Resource Economics (2nd ed., pp. 1-17). Netherlands: Kluwer Academic Publishers. https://doi.org/10.1007/BF00324686

Burley, J. (1997). Foreword. In African Rainforests and the Conservation of Biodiversi- 
ty-Proceedings of the Limbe Conference. Limbe: Limbe Botanic Garden.

Cross River State Forestry Project (ODA Assisted) (1994). Report of the Reconnaissance Inventory of High Forest and Swamp Forest Areas in Cross River State, Nigeria. Calabar, Forestry Department Headquarters.

DFID (2002). Cross River State Forest Inventory Report. A DFID Assisted Project Outcome on Cross River State Forestry Project, 1999-2002, at Calabar, Nigeria. London: DFID.

Dunn, R. M., \& Otu, D. (1996). A Community Inventory for Productive Forest Management in Cross River State, Nigeria. In: Carter, J. (Ed), Recent Approaches to Participatory Forest Resource Assessment. Londod: ODI.

Edet, D. I., Ijeomah, H. I., \& Ogogo, A. U. (2015). Preliminary Assessment of Tree Species Diversity in Afi Mountain Wildlife Sanctuary, Southern Nigeria. Agriculture and Biology Journal of North America, 3, 486-492. https://doi.org/10.5251/abjna.2012.3.12.486.492

Enuoh, O. O. O. (2012). Buffer Zone Communities, Commercial Bush Meat Hunting and Biodiversity Conservation in Cross River National Park, Nigeria. A PhD Thesis at the School of Agriculture, Policy and Development. Reading: University of Reading.

FAO (2010). FAO Forestry Paper 163: Global Forest Resource Assessment 2010 Main Report. Rome: FAO Publication.

IUCN. (1996). Communities and Forest Management with Recommendations to the Intergovernmental Panel on Forests. Washington DC: IUCN.

Lengeler, J. C. (1997). Local People's Participation in Forest Resource Assessment: A Review of Field Experience. In African Rainforests and the Conservation of Biodiversity-Proceedings of the Limbe Conference. Limbe: Limbe Botanic Garden.

Lord, B., \& Norton, W. W. (1990). Biogeochemistry: An Analysis of Global Change. San Diego: Academic Press.

Marguba, L. B. (2003). Protected Areas in National and Regional Development. In The Road to Durban: Regional Protected Areas Workshop for West and Central Africa. Kribi: IUCN.

McLetchie, B. (2002). Effects of Habitat Fragmentation on the Reproductive Systems. Princeton, NJ: Princeton University Press.

Oates, J. F. (2002). West Africa: Tropica Forest Parks on the Brink. In: Terborgh, et al. (Eds). Making Parks Work: Strategies for Preserving Tropical Nature. Washington DC: Island Press.

Ojong, I. (1996). The Preservation vs. Utilization Paradox in Managing the Remaining Rainforest of South Eastern Nigeria: Contribution towards Conflict Resolution. In Proceedings of Workshop on the Rainforest of South Eastern Nigeria and South West Cameroon. Obudu Cattle Ranch: Cross River National Park.

Sale, F. A., Samuel, D., \& Ayo-Odifin, O. S. (2008). Effects of Climate Change on Biodiversity. In L. Popoola (Ed.), Proceedings of the 32nd Annual Conference of the Forestry Association of Nigeria (pp. 202-207). Ibadan: FAN.

Terborgh, J., \& Schaik, C. V. (2002). Why the World Needs Parks. In J. Terborgh, C. V. Schaik, L. Davenport, \& M. Rao, (Eds.). (2002), Making Parks Work: Strategies for Preserving Tropical Nature. Washington DC: Island Press.

WCS/Okeke, O. F. (2013). Land Cover Change Analysis in the Afi-Mbe-Okwangwo Landscape of Cross River State, Nigeria. A GIS Report.

World Bank (1985). Ivory Coast: Second Forestry Project-Staff Appraisal Report. Washington DC. 
WWF/ODNRI (1989). Cross River National Park: Oban Division: Land Evaluation and Agricultural Recommendations. London: WWF/ODNRI.

WWF/ODNRI (1989). Cross River National Park: Oban Division: Plan for Developing the Park and Its Support Zone. London: WWF/ODNRI.

WWF/ODNRI (1990). Cross River National Park: Plan for Developing the Park and Its Support Zone. A Project Document Prepared by WWF in Collaboration with ODNRI for the Federal Republic of Nigeria and the Cross River State Government. London: WWF. 